\title{
Erratum to: Three-dimensional power Doppler study of changes in uterine vascularity after absorbable cervical tourniquet during open myomectomy
}

Manal M. El Behery • Moustafa M. Zaitoun •

Soha Siam - Moustafa A. Ibraheim

Published online: 6 August 2013

(C) Springer-Verlag Berlin Heidelberg 2013

Erratum to: Arch Gynecol Obstet (2011) 284:157-161

DOI 10.1007/s00404-010-1615-x

The name of author Sohasaim was published incorrectly.

The correct name should read as Soha Siam (S. Siam).

The online version of the original article can be found under doi:10.1007/s00404-010-1615-x.

M. M. El Behery · M. M. Zaitoun · S. Siam · M. A. Ibraheim Department of Obstetrics and Gynecology, Faculty of Medicine,

Zagazig University Hospitals, Zagazig, Egypt

M. M. El Behery $(\bowtie)$

Department of Obstetrics and Gynecology,

Faculty of Medicine, Zagazig University, Zagazig, Egypt

e-mail: mbhry@hotmail.com 